OPEN ACCESS

Edited by:

lan Moore,

University of Oxford, United Kingdom

Reviewed by:

Zhaojun Ding,

Shandong University, China

Caiji Gao,

South China Normal University, China

*Correspondence:

Francisco J. Pérez

frperez@uchile.c

Specialty section:

This article was submitted to

Plant Cell Biology,

a section of the journal

Frontiers in Plant Science

Received: 26 October 2016

Accepted: 01 May 2017

Published: 19 May 2017

Citation:

Vergara $R$, Noriega $X$, Aravena $K$,

Prieto H and Pérez FJ (2017)

ABA Represses the Expression of Cell

Cycle Genes and May Modulate

the Development of Endodormancy

in Grapevine Buds.

Front. Plant Sci. 8:812.

doi: 10.3389/fpls.2017.00812

\section{ABA Represses the Expression of Cell Cycle Genes and May Modulate the Development of Endodormancy in Grapevine Buds}

\author{
Ricardo Vergara ${ }^{1,2}$, Ximena Noriega $^{1}$, Karla Aravena ${ }^{1}$, Humberto Prieto ${ }^{3}$ and \\ Francisco J. Pérez ${ }^{1 *}$ \\ 1 Laboratorio de Bioquímica Vegetal, Facultad de Ciencias, Universidad de Chile, Santiago, Chile, ${ }^{2}$ Programa Doctorado en \\ Ciencias Silvoagropecuarias y Veterinarias, Universidad de Chile, Santiago, Chile, ${ }^{3}$ Laboratorio de Biotecnología Vegetal, \\ Instituto de Investigaciones Agropecuarias, La Platina, Santiago, Chile
}

Recently, the plant hormone abscisic acid (ABA) has been implicated as a key player in the regulation of endodormancy (ED) in grapevine buds (Vitis vinifera L). In this study, we show that in the vine, the expression of genes related to the biosynthesis of ABA (VvNCED1; VvNCED2) and the content of ABA are significantly higher in the latent bud than at the shoot apex, while the expression of an ABA catabolic gene ( $V v A 8 H 3)$ showed no significant difference between either organ. A negative correlation between the content of ABA and transcript levels of cell cycle genes (CCG) was found in both tissues. This result suggested that $A B A$ may negatively regulate the expression of CCG in meristematic tissues of grapevines. To test this proposition, the effect of ABA on the expression of CCG was analyzed in two meristematic tissues of the vine: somatic embryos and shoot apexes. The results indicated that cell cycle progression is repressed by ABA in both organs, since it down-regulated the expression of genes encoding cyclin-dependent kinases ( $\left.V v C D K B 1, V_{V} C D K B 2\right)$ and genes encoding cyclins of type $A\left(V_{v} C Y C A 1, V_{v} C Y C A 2, V_{v} C Y C A 3\right), B(V v C Y C B)$, and $D\left(V_{v} C Y C D 3.2 a\right)$ and up-regulated the expression of $V V I C K 5$, a gene encoding an inhibitor of CDKs. During $\mathrm{ED}$, the content of ABA increased, and the expression of CCG decreased. Moreover, the dormancy-breaking compound hydrogen cyanamide $(\mathrm{HC})$ reduced the content of $\mathrm{ABA}$ and up-regulated the expression of CCG, this last effect was abolished when $\mathrm{HC}$ and ABA were co-applied. Taken together, these results suggest that ABA-mediated repression of CCG transcription may be part of the mechanism through which $A B A$ modulates the development of ED in grapevine buds.

Keywords: abscisic acid (ABA), cell cycle genes, endodormancy, grapevine buds

\section{INTRODUCTION}

The central role of the plant hormone abscisic acid (ABA) in the control of seed dormancy is well established (Graeber et al., 2012). However, its role in the control of bud dormancy in woody perennials is not well defined. In poplar, the participation of ABA in the development of endodormancy (ED) induced by a short-day (SD)-photoperiod has been proposed, as both the content of $\mathrm{ABA}$ and $\mathrm{ABA}$ biosynthesis related genes peaked after 3-4 weeks of SD-treatment 
(Arora et al., 2003; Rohde and Bhalerao, 2007; Ruttink et al., 2007). Additionally, in parallel to increases in ABA content, several cell cycle genes (CCG) show decreased expression (Ruttink et al., 2007). However, because the content of ABA is very low when the dormant state is achieved (Ruttink et al., 2007), some doubts have been raised regarding the role of ABA in maintaining dormancy (Olsen, 2010).

In contrast to poplar and other tree species, Vitis does not set a terminal bud in response to SD-photoperiod, and the shoot apex does not enter ED, but the latent buds do (Kühn et al., 2009; Grant et al., 2013). During ED, the expression of ABA biosynthesis-related genes increased, while the expression of ABA catabolism-related genes decreased, and the content of ABA increased (Zheng et al., 2015). Exogenous application of ABA inhibited the release of buds from ED and attenuated the effect of the dormancy-breaking compound hydrogen cyanamide (HC), which promoted bud release (Zheng et al., 2015). Moreover, a SD photoperiod triggered the development of ED in grapevine buds (Kühn et al., 2009; Grant et al., 2013) and up-regulated the expression of ABA biosynthesis-related genes $V v N C E D 1$ and VvNCED2 (Parada et al., 2016). All this evidence supports the hypothesis that $\mathrm{ABA}$ promotes $\mathrm{ED}$ in grapevine buds. However, how this occurs is not well understood. ED, or winter rest, is characterized by reduced activity of the meristem of the latent bud and by the lack of response to growthpromoting stimuli (Rohde and Bhalerao, 2007). ABA and other hormones, such as gibberellins (GAs), auxin and cytokinin (CK) are well known to control the expression of CCG, which is certainly relevant in the development of ED (Campbell et al., 2014).

Progression of the cell cycle is primarily controlled by universally conserved cyclin-dependent kinases (CDKs) (Pines, 1995). Eight classes of CDKs were defined in Arabidopsis based on phylogenetic analyses (Vandepoele et al., 2002), but only the CDKA and CDKB groups have been well studied. CDKA is closely related to yeast $\mathrm{Cdcd} 2 / \mathrm{Cdc} 28$ and to human $\mathrm{CDK} 1$, CDK2, and CDK3 (Hirt et al., 1992). CDKB is a plant-specific $\mathrm{CDK}$ that can be divided into two subgroups, CDKB1 and CDKB2. CDKB1 transcripts accumulate during S, G2 and $M$ phase, and in barley, this gene is down-regulated by ABA (Gendreau et al., 2012). CDKB2 expression is specific to the G2 and $\mathrm{M}$ phases. $\mathrm{CDK}$ activity is negatively regulated by binding of the INHIBITOR OF CDK/KIP-RELATED PROTEIN (ICK) (De Veylder et al., 2001). ICK induces arrest or delay of the cell cycle in response to intra- or extracellular signals (Verkest et al., 2005). The activity and substrate specificity of CDKs are dependent upon their association with cyclins (Morgan, 1995). In plants, type $\mathrm{A}, \mathrm{B}$ and $\mathrm{D}$ cyclins are thought to play a major role in cell cycle control (de Jager et al., 2001). The A- and B-type cyclins are expressed from $S$ to $M$ phase and control DNA replication, the G2/M transition and mitosis. The D-type cyclins are thought to be sensors of external signals and to play an essential role in cell cycle progression and in the entry of quiescent cells into the cell cycle (Kono et al., 2007). In the Vitis genome, the following cell cycle related genes have been identified: three CDKs, $V v C D K A, V v C D K B 1$ and $V v C D K B 2$; two ICKs, VvICK5, VvICK7; two ICK-like genes, VvICK3-like,
VvICK7-like; three type A cyclins, VvCYCA1, VvCYCA2, and $V v C Y C A 3$; one type B cyclin, $V v C Y C B$; and three type $\mathrm{D}$ cyclins, $V v C Y C D 3.1, V v C Y C D 3.2 a$, and $V v C Y C D 3.2 b$.

In this study, we postulated that $\mathrm{ABA}$, by repressing the expression of CCG, can modulate the development of ED in grapevine buds.

\section{MATERIALS AND METHODS}

\section{Plant Material}

Latent buds and the shoot apexes from 8-year-old Vitis vinifera $\mathrm{cv}$. Thompson seedless grown at the experimental station at the Chilean National Institute of Agriculture Research (INIA) in Santiago, Chile $\left(33^{\circ} 34^{\prime} \mathrm{S}\right.$ latitude) were collected on the same dates 7 March because it has been previously reported that the transition from paradormancy (PD) to ED occurs in midJanuary (Kühn et al., 2009). Grape somatic embryos (GSE) used as plant material were initiated from a leaf disk of in vitro micropropagated Vitis vinifera cv. Thompson seedless plantlets. NB2 culture medium (Dhekney et al., 2009) was used for callus micropropagation, and cultures were maintained in the dark at $24^{\circ} \mathrm{C}$ until the formation of callus, when GSE were separated from the callus tissue and transferred to X6 medium and sub-cultured monthly. All samples were frozen in liquid $\mathrm{N}_{2}$ and stored at $-80^{\circ} \mathrm{C}$ until used.

\section{ABA Treatment}

For ABA treatment, GSE, the shoot apexes and latent buds of grapevines cv. Thompson seedless were sprayed with ABA (Sigma-Aldrich, United States) at concentrations of 10 and $100 \mu \mathrm{M}$, respectively, and water was used as a control. For GSE experiments, $0.3 \mathrm{~g}(0.1 \mathrm{~g}$ for each replicate) of GSE, mostly in the globular to heart-shaped stage, were transferred from subculture of semi-solid growth regulator-free X6 medium to liquid X6 medium. The effect of ABA $(10 \mu \mathrm{M})$ on GSE was tested in a final volume of $30 \mathrm{ml}$ of liquid X6 medium. Samples were shaken at $115 \mathrm{rpm}$ for $72 \mathrm{~h}$, and afterward, the liquid medium was discarded, and the GSE were frozen at $-80^{\circ} \mathrm{C}$ until used. Shoot apexes were obtained from one month shoots from single-bud cuttings grown in a growth chamber and sprayed with $100 \mu \mathrm{M}$ ABA. Samples were collected $24 \mathrm{~h}$ after the treatment, frozen in liquid $\mathrm{N}_{2}$ and stored at $-80^{\circ} \mathrm{C}$ until used. Latent buds collected on March 23 were used to measure the content of ABA within the buds $48 \mathrm{~h}$ after the application of a $100 \mu \mathrm{M}$ ABA solution, 2.5\% $\mathrm{HC}$ solution and co-application of ABA and $\mathrm{HC}$ solutions.

\section{Hydrogen Cyanamide Treatment}

The effect of the dormancy-breaking compound HC (SigmaAldrich, United States) on the expression of CCG and ABA metabolism-related genes was studied on single-bud cuttings of Thompson seedless grapevines. Canes collected on 8 June, 2015 were cut into single-bud cuttings. Cuttings (10-12 cm length) were sprayed with an aqueous solution containing $2.5 \% \mathrm{HC}$, and water was used as a control. Subsequently, the cuttings were placed in a growth chamber set at $23 \pm 1^{\circ} \mathrm{C}$ with a $16 \mathrm{~h}$ 
photoperiod; $48 \mathrm{~h}$ after $\mathrm{HC}$ application, samples were taken for gene expression analysis.

\section{Extraction and Purification of ABA}

Fresh plant material (10 buds and approximately $0.1 \mathrm{~g}$ of shoot apex for each biological replicate) was powdered in liquid nitrogen. The samples were extracted in a shaker for $1 \mathrm{~h}$ at $4^{\circ} \mathrm{C}$ and $10 \mathrm{~min}$ by ultra-sonication with $3 \mathrm{ml}$ of $80 \%$ methanol containing $1 \%$ acetic acid and 3 ng of 2,3,5-triiodobenzoic acid (TIBA) as an internal standard (Sigma-Aldrich, United States). The extracts were centrifuged at $3000 \times g$ for $10 \mathrm{~min}$, and the supernatant was filtered through glass wool and a Sep-Pack $C_{18}$ cartridge (Waters Assoc., Milford, MA, United States) that had been prewashed with $5 \mathrm{ml}$ of $80 \%$ methanol. The procedure was repeated twice, and the filtrate was evaporated to dryness. After evaporation, the residue was dissolved in $1.2 \mathrm{ml}$ ethyl acetate, and $1.2 \mathrm{ml}$ of $0.5 \mathrm{M} \mathrm{KH}_{2} \mathrm{PO}_{4} \mathrm{pH} 3.0$ was added. The mixture was agitated with a vortex and centrifuged at $3000 \mathrm{rpm}$ for $3 \mathrm{~min}$. After centrifugation, the ethyl acetate layer was removed and placed in a clean tube. The aqueous phase was extracted once more with $1.2 \mathrm{ml}$ of ethyl acetate. The collected ethyl acetate layers $(2.4 \mathrm{ml})$ were evaporated to dryness. The samples were dissolved in $3 \mathrm{ml}$ of ethylic ether and methylated with diazomethane in a diazomethane-generator apparatus according to manufacturer's instructions. After methylation, the ether solution was evaporated to dryness, and the residue was dissolved in $50 \mu$ l methanol.

\section{Gas Chromatography Determination of ABA}

A Shimadzu gas chromatograph, model GC-2014, equipped with an electron capture detector (ECD-2014, Shimadzu Corporation, Kyoto, Japan) and computer integrator was used for ABA determination (Vermeer et al., 1987). A CBP1 capillary column ( $25 \mathrm{~m} \times 0.25 \mathrm{~mm}$ I.D.) with helium as the carrier gas at a flux of $1.5 \mathrm{ml} \mathrm{min}{ }^{-1}$ was used. The initial temperature of the column was $80^{\circ} \mathrm{C}$ and after $1 \mathrm{~min}$ was raised to $270^{\circ} \mathrm{C}$ at a rate of $20^{\circ} \mathrm{C}$ per min and maintained for $5 \mathrm{~min}$. The injector was operated in the "splitless" mode at $225^{\circ} \mathrm{C}$, and the temperature of the detector was $300^{\circ} \mathrm{C}$. A calibration curve for ABA methyl ester and TIBA methyl ester was constructed. Endogenous ABA content was calculated from the peak area ratios of endogenous ABA to internal TIBA standard (Vermeer et al., 1987).

\section{RNA Purification and cDNA Synthesis}

For gene expression analysis, total RNA was isolated and purified from GSE ( $0.1 \mathrm{~g}$ fr.wt), shoot apexes ( $0.1 \mathrm{~g}$ fr.wt) and latent buds $(0.5 \mathrm{~g}$ fr.wt) of Vitis vinifera $\mathrm{cv}$. Thompson seedless. In all cases, total RNA was extracted and purified using a modification of the method of Chang et al. (1993), as described in Noriega et al. (2007). DNA was removed by treatment with RNase-free DNase

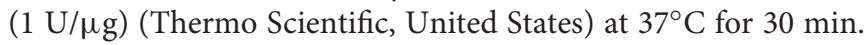
First-strand cDNA was synthesized from $1 \mu \mathrm{g}$ of purified RNA with $1 \mu \mathrm{L}$ oligo $(\mathrm{dT})_{12-18}\left(0.5 \mu \mathrm{g} \times \mu \mathrm{L}^{-1}\right)$ as a primer, $1 \mu \mathrm{L}$ dNTP mix $(10 \mathrm{mM})$ and Superscript ${ }^{\circledR}$ II RT (Invitrogen, CA, United States).

\section{Quantitative Real-Time PCR}

Quantitative real-time PCR (RT-qPCR) was carried out in an Eco Real-Time PCR system (Illumina, Inc. San Diego, United States) using KAPA SYBR FAST (KK 4602) qPCR Master Mix (2 X). Primers for CDKs ( $v v C D K A, V v C D K B 1$, $V v C D K B 2), \quad C D K$ inhibitors (VvICK5, VvICK7), ICK-like genes (VvICK3-like; VvICK7-like), type A cyclins (VvCYCA1, $V v C Y C A 2, \quad V v C Y C A 3)$, type $\mathrm{B}$ cyclins $(V v C Y C B)$, type $\mathrm{D}$ cyclins ( $V v C Y C D 3.1, \quad V v C Y C D 3.2 a, \quad V v C Y C D 3.2 b)$ and ABA metabolism-related genes ( $V v N C E D 1, \quad V v N C E D 2, \quad V v A 8 H 3)$ were designed using the PRIMER3 software (Rozen and Skaletsky, 2000) (Supplementary Table S1). cDNA was amplified under the following conditions: denaturation at $94^{\circ} \mathrm{C}$ for $2 \mathrm{~min}$ and 40 cycles of $94^{\circ} \mathrm{C}$ for $30 \mathrm{~s}, 55^{\circ} \mathrm{C}$ for $30 \mathrm{~s}$, and $72^{\circ} \mathrm{C}$ for $45 \mathrm{~s}$. Relative changes in gene expression levels were determined using the $2^{-\Delta \Delta C T}$ method (Livak and Schmittgen, 2001). Each reaction was performed in at least three biological replicates, each with three technical replicates. $V v U B I Q U I T I N$ and/or VvACTIN were used as a reference gene for normalization

\section{Statistical Analysis}

Differences in gene expression at different times were analyzed by ANOVA, and multiple comparison analysis was carried out by Dunnett's and Tukey's methods $(\alpha=0.05)$. For pairwise comparisons, the Student's $t$-test $(\alpha=0.05)$ method was used.

\section{RESULTS}

\section{Expression of ABA Metabolism-Related Genes and ABA Content in Latent Buds and Shoot Apexes of Vines}

In grapevines, transcript levels of the ABA biosynthesis genes $V v N C E D 1$ and $V v N C E D 2$ were significantly more highly expressed in the latent buds than at the shoot apexes (Figure 1A), while transcript levels of ABA catabolic gene $V v A 8 H 3$ showed no significant difference between either organ (Figure 1A). As expected, the content of ABA was higher in the latent buds than in the shoot apexes (Figure 1B).

\section{Expression of CCGs in the Latent Buds and Shoot Apexes of Vines}

The following cell cycle-related genes have been identified in the Vitis genome: three CDK, $V v C D K A, V v C D K B 1$, and $V v C D K B 2$; two CDK inhibitors, VvICK5, VvICK7; two ICK-like genes, VvICK3-like, VvICK7-like; three type A cyclins, VvCYCA1, $V v C Y C A 2$, and $V v C Y C A 3$; one type B cyclin, $V v C Y C B$; and three type D cyclins, $V v C Y C D 3.1, V v C Y C D 3.2 a$, and $V v C Y C D 3.2 b$. Transcript levels of CDKs $V v C D K B 1$ and $V v C D K B 2$ were expressed more highly at the shoot apex than at the latent bud, while $V v C D K A$ was expressed similarly in both organs (Figure 2A). Expression analysis of type A cyclins, $V v C Y C A 1$, $V v C Y C A 2, V v C Y C A 3$; type $\mathrm{B}$ cyclin, $V v C Y C B$; and type $\mathrm{D}$ cyclins, $V v C Y C D 3.1, V v C Y C D 3.2 a, V v C Y C D 3.2 b$, showed that all of them were expressed more at the shoot apex than 


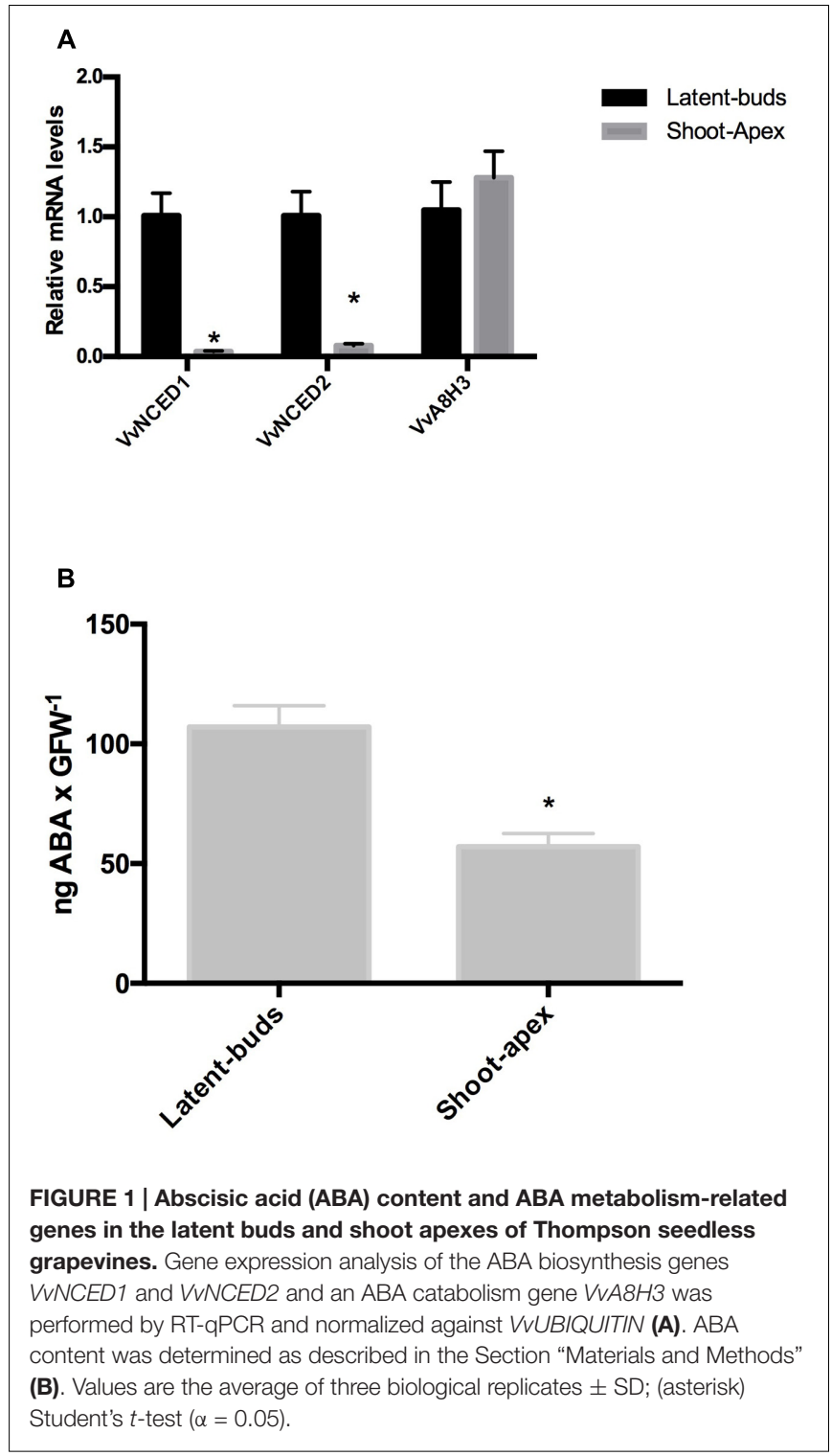

at the latent buds (Figure 2B). In contrast, the transcript levels of the CDK inhibitors VvICK5, VvICK7 and VvICK7like were higher in the latent buds than at the shoot apexes, while VvICK3-like was expressed more at the shoot apex (Figure 2C).

\section{ABA Down-regulated the Expression of CCGs in GSEs}

To verify whether ABA affects the expression of CCGs in meristematic tissues of grapevines, we analyzed its effect on the expression of the CDKs $V v C D K A, V v C D K B 1, V v C D K B 2$ (Figure 3A), the type A cyclins $V v C Y C A 1, V v C Y C A 2, V v C Y C A 3$, the type B cyclin $V v C Y C B$, and the type D cyclins $V v C Y C D 3.1$, $V v C Y C D 3.2 a, \quad V v C Y C D 3.2 b$ (Figure 3B) and on the CDK inhibitors VvICK5 and VvICK7 and two ICK-like genes, VvICK3-like and VvICK7-like genes (Figure 3C) in GSE. The results indicated that $\mathrm{ABA}$ inhibits cell cycle progression

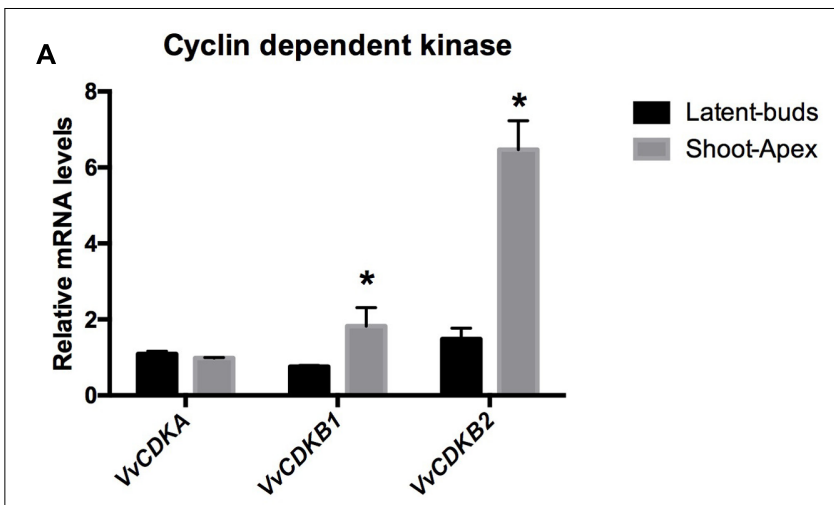

B

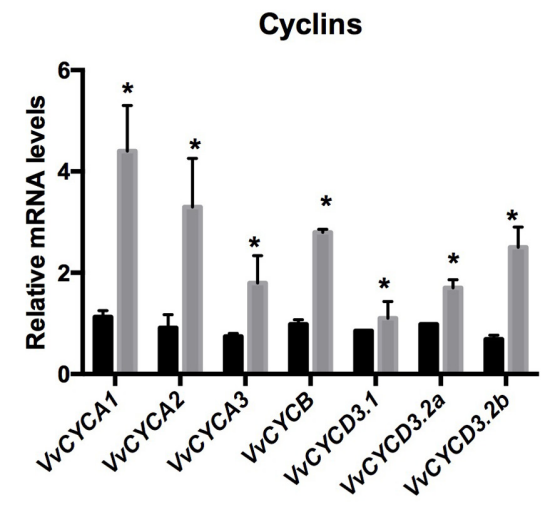

C Inhibitors CDK

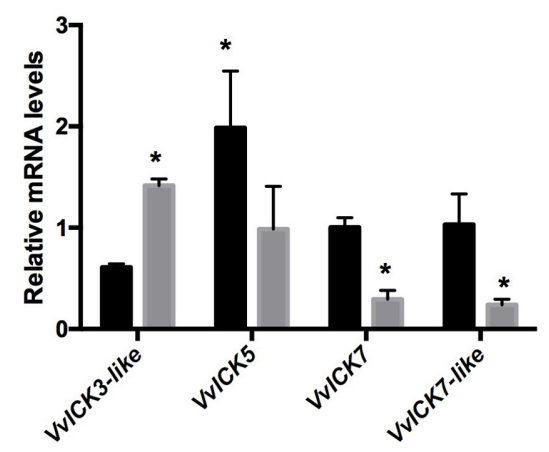

Latent-buds

Shoot-Apex

FIGURE 2 | Difference in gene expression of (A) cyclin-dependent kinases ( $V v C D K s)$, (B) cyclins ( $V v C Y C s)$, and (C) inhibitors of CDKs (VvICKs) in latent buds and shoot apexes. Gene expression analysis was performed by RT-qPCR and normalized against VVUBIQUITIN. Values are the average of three biological replicates with three technical repetitions \pm SD; (asterisk) Student's $t$-test $(\alpha=0.05)$.

since most of the genes coding for CDKs ( $V v C D K s)$ and for cyclins $(V v C Y C s)$ were down-regulated by the plant hormone (Figures 3A,B), while the expression of a $\mathrm{CDK}$ inhibitor (VvICK5) was up-regulated (Figure 3C). Similar results were obtained when ABA was applied to other organs containing meristems, such as the shoot-apex (Supplementary Figure S1). 


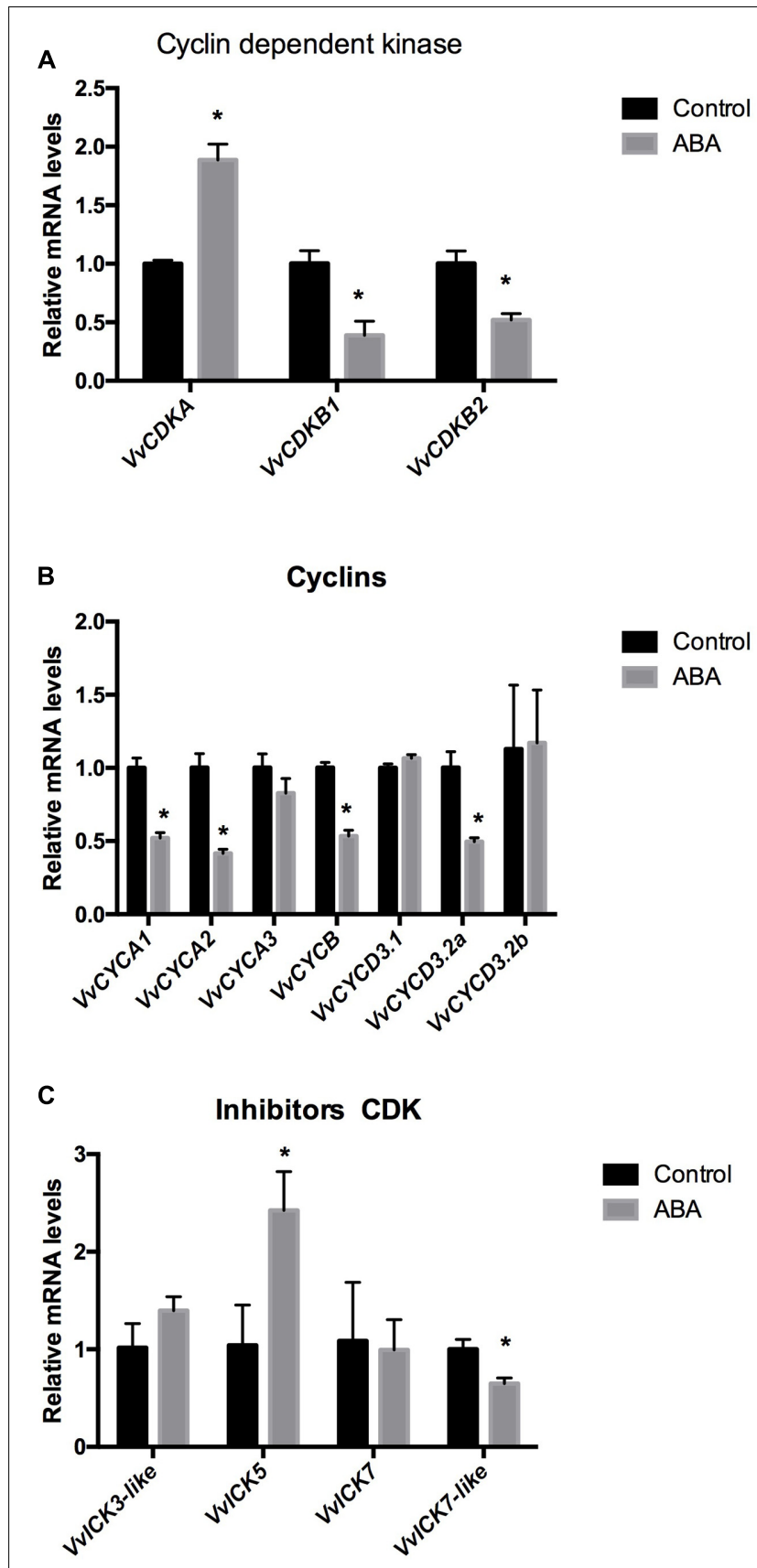

FIGURE 3 | Effect of ABA on the expression of (A) cyclin-dependent kinases ( $V v C D K s),(\mathbf{B})$ cyclins $(V v C Y C s)$ and (C) inhibitors of CDKs ( $V v / C K s)$ on Thompson seedless somatic embryos.Gene expression analysis was performed by RT-qPCR and normalized against VVACTIN. Values are the average of three biological replicates with three technical repetitions $\pm \mathrm{SD}$; (asterisk) Student's $t$-test $(\alpha=0.05)$.

\section{Changes in the Expression of CCG during ED in Grapevine Buds}

It has been reported that the content of $\mathrm{ABA}$ increases with the development of ED in grapevine buds (Zheng et al., 2015). To test whether this increase is consistent with a decrease in the expression of CCG, transcript levels of CCG taken from microarray data on the development of Tempranillo grape buds grown in the Northern Hemisphere (Díaz-Riquelme et al., 2012) were plotted throughout the ED period (Figures 4A-C). Furthermore, to verify the data of Díaz-Riquelme et al. (2012), we used RT-qPCR to analyze the transcript levels of CCG in buds of Thompson seedless grapevines grown in the Southern Hemisphere (Figures 4D-F). The results showed that in either cases, the expression of $V v C D K s$ (Figures 4A,D) and $V v C Y C s$ (Figures 4B,E) decreased with the development of the ED, while the expression of $V v I C K 5$ increased, and the expression of $V v I C K 7$ decreased while VvICK7-like and VvICK3-like remained relatively unchanged (Figures 4C,F).

\section{Hydrogen Cyanamide Reduced the Content of ABA in Grapevine Buds}

To test whether $\mathrm{HC}$ reduces the content of $\mathrm{ABA}$ in grapevine buds, single-bud cuttings of cv. Thompson seedless were sprayed with a $2.5 \%$ solution of $\mathrm{HC}$, and $48 \mathrm{~h}$ after treatment, analysis was conducted for the ABA biosynthesis-related gene $V v N C E D 2$, the ABA catabolism-related gene $V v A 8 H 3$ and ABA content. The results showed that $\mathrm{HC}$ down-regulated $V v N C E D 2$ (Figure 5A) and up-regulated $V v A 8 H 3$ gene expression (Figure 5B) and $\mathrm{ABA}$ content was drastically reduced (Figure 5C).

\section{Hydrogen Cyanamide Up-regulated the Expression of CCG}

To test whether HC up-regulates the expression of CCG in grapevine buds, single-bud cuttings of cv. Thompson seedless were sprayed with a $2.5 \%$ solution of $\mathrm{HC}$, and $48 \mathrm{~h}$ after treatment, gene expression analysis was conducted. The results showed that $\mathrm{HC}$ up-regulated the expression of the CDK $V v C D K B 1$ (Figure 6A) and of the A-type cyclins $V v C Y C A 2$ and $V v C Y C A 3$; however, the expression of $V v C Y C D s$ was inhibited (Figure 6B), and the expression of CDK inhibitors, VvICK5 and VvICK7, was down-regulated (Figure 6C).

\section{Incorporation of ABA into Grapevine Buds}

To determine the content of ABA within the buds after spraying them with the following solutions; $100 \mu \mathrm{M} \mathrm{ABA}$, $100 \mu \mathrm{M} \mathrm{ABA}+2.5 \% \mathrm{HC}, 2.5 \% \mathrm{HC}$, single-bud cuttings harvested on March 23 were sprayed with the above solutions and water as control, $48 \mathrm{~h}$ after the treatment, analysis was conducted to determine the ABA content. The results indicated that the application of $100 \mu \mathrm{M}$ ABA doubled the concentration of $\mathrm{ABA}$ in relation to control buds, while the application of $\mathrm{HC}$, reduced the concentration of $\mathrm{ABA}$ to half of the concentration of the control, and co-application of $\mathrm{ABA}$ and $\mathrm{HC}$ resulted in $\mathrm{ABA}$ content similar to control buds (Figure 7A). To test if the modifications produced by $\mathrm{HC}$ on the expression of CCG are due to their reducing effect on the ABA content, single-bud cuttings of grapevines were sprayed with the following solutions $2.5 \% \mathrm{HC} ; 2.5 \%$ $\mathrm{HC}+100 \mu \mathrm{M}$ ABA and water as control. Expression of genes that were up-regulated by $\mathrm{HC}$ were analyzed 
A

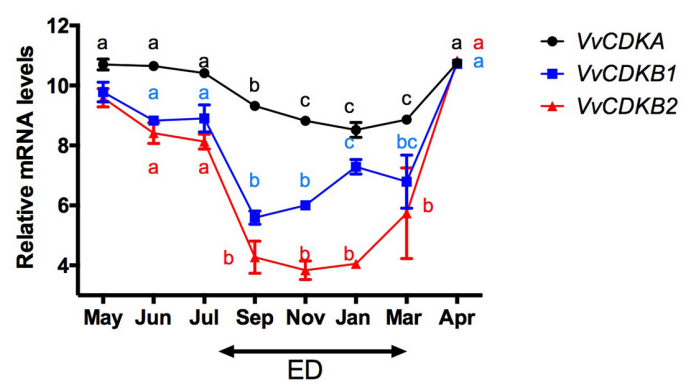

B

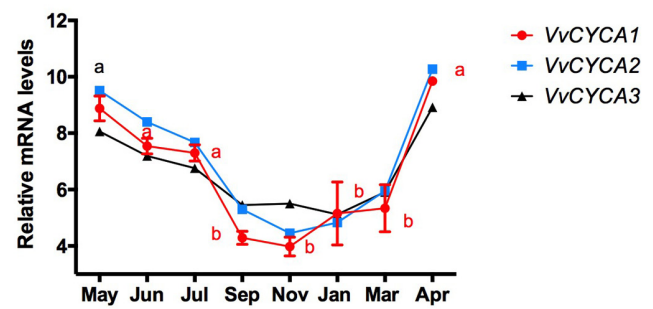

C

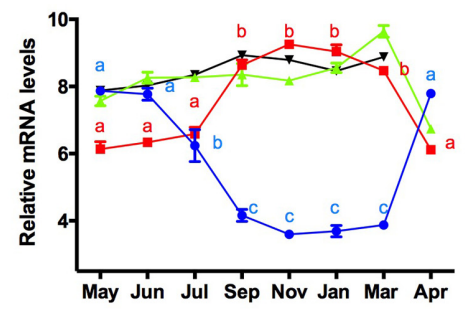

D

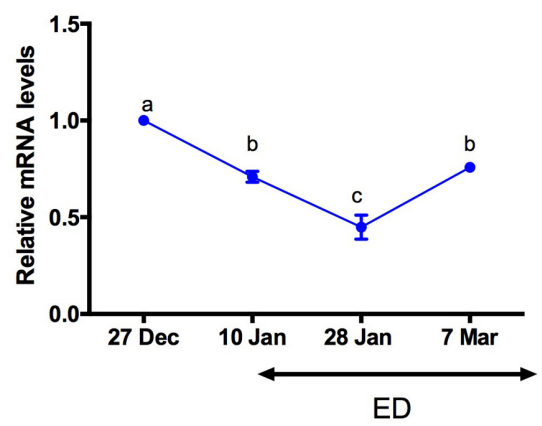

E

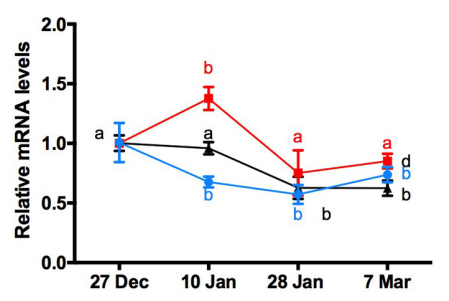

- VVCYCA3

- VvCYCD 3.1

- $V_{v} C Y C D 3.2 b$
$\mathbf{F}$

$\rightarrow V V I C K 7$

- VVICK5

- VvICK7-like

- VvICK3-like
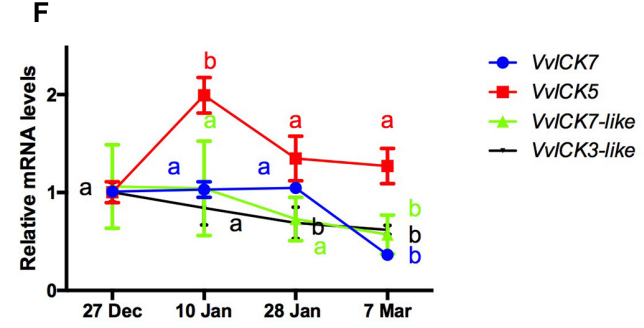

FIGURE 4 | Changes in the expression of (A) cyclin-dependent kinases (VvCDKs), (B) cyclins ( $V v C Y C s)$, and (C) inhibitors of $C D K s$ ( $V v / C K s)$ during the development of endodormancy (ED) in Tempranillo grapevine buds grown at the Northern Hemisphere and in Thompson seedless grapevine buds grown in the Southern Hemisphere (D-F). Values for Tempranillo grapevine buds were taken from (Díaz-Riquelme et al., 2012), and those for Thompson seedless were determined by RT-qPCR and normalized against VVUBIQUITIN. Values for Tempranillo and Thompson seedless are the average of three biological replicates with three technical repetitions \pm SD. Different lower case letters represent significant differences between transcript collected from grapevine buds at different times

Tukey's test $(\alpha=0.05)$.

$48 \mathrm{~h}$ after treatment. The results showed that transcript levels of $V v C D K B 1, V v C Y C A 3$, and $V v I C K 5$ remained similar to control buds after the co-application of $\mathrm{HC}$ and $\mathrm{ABA}$ (Figures 7B-D).

\section{DISCUSSION}

Abscisic acid has been shown to inhibit DNA replication in root tips and embryos of Fraxinus excelsior (Van Overbeek et al.,
1967; Villiers, 1968). It has also been described as an inhibitor of cell division and/or DNA synthesis in different plant cell types (Newton, 1977; Robertson et al., 1990). Using a construct in which expression of the $B$-glucuronidase (GUS) reporter gene was driven by the CDKA promoter, Hemerly et al. (1993) demonstrated that $\mathrm{ABA}$ inhibits promoter activity in the root. On the other hand, ABA induced the expression of the cyclindependent protein kinase inhibitor (ICK/KRP) (Wang et al., 1981), and it has been suggested that ABA blocks cell division at the G1/S transition by increasing the levels of ICK/KRP 
A

\section{VvNCED2}

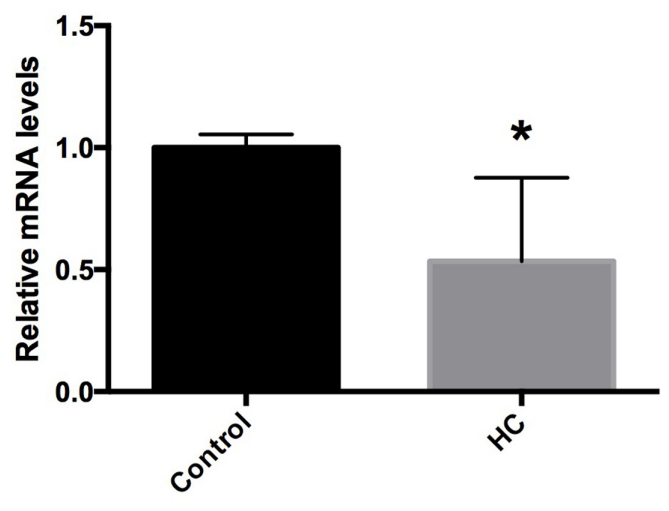

B

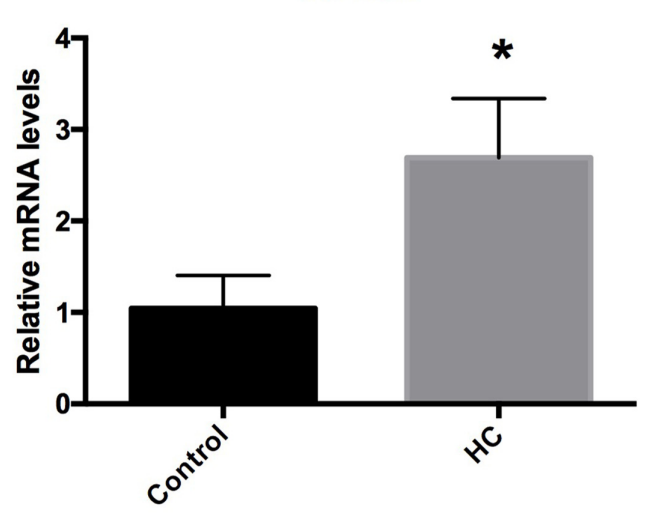

C

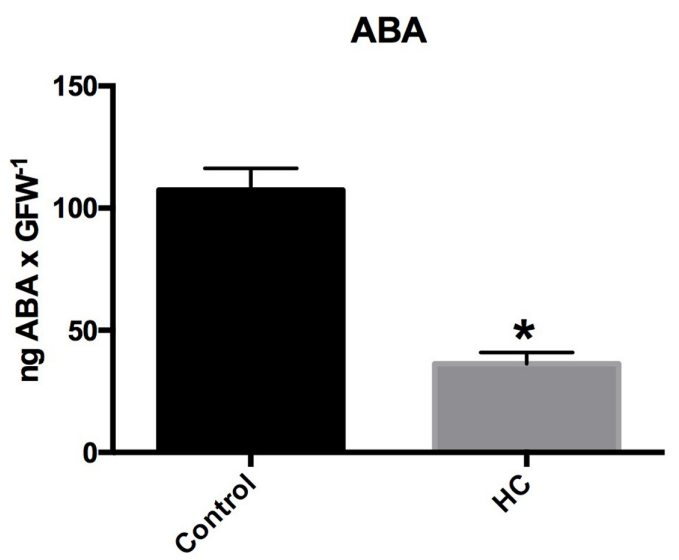

FIGURE 5 | Hydrogen cyanamide $(\mathrm{HC})$ altered the expression of $A B A$ metabolism-related genes $(\mathbf{A}, \mathbf{B})$ and reduced the content of $A B A$ in grapevine buds (C). HC down-regulated the expression of the ABA biosynthesis gene VVNCED2 (A) and up-regulated the expression of the ABA catabolism-related gene $V_{V A B H}$ (B) and reduced the content of ABA (C) in Thompson seedless grapevine buds. Gene expression analysis was performed by RT-qPCR, values were normalized against VVUBIQUITIN, and the content of $A B A$ was determined as described in the Section "Materials and Methods". Values are the average of three biological replicates with \pm SD; (asterisk) Student's $t$-test $(\alpha=0.05)$.

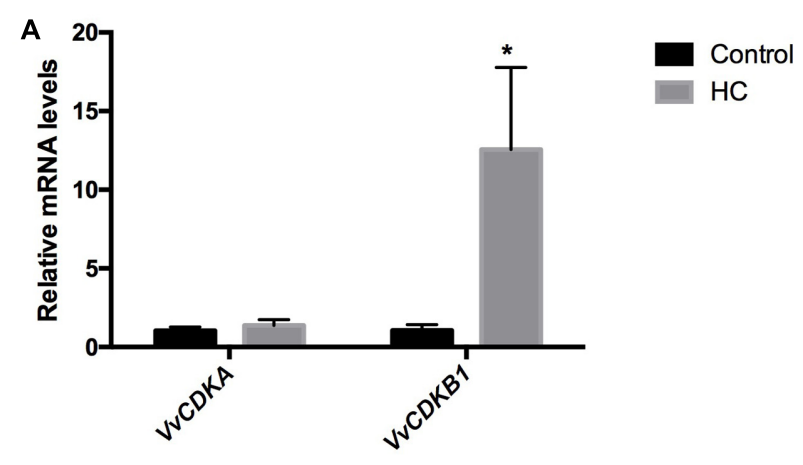

B

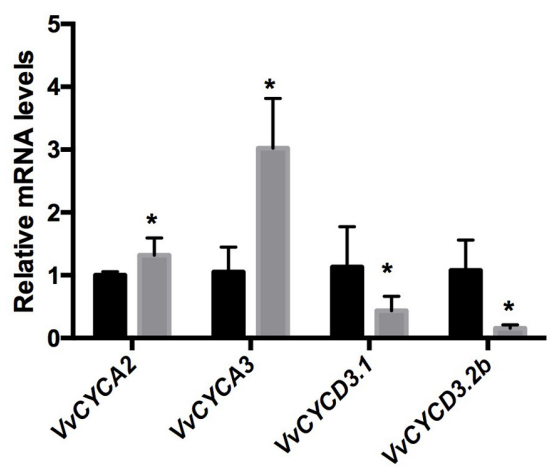

C

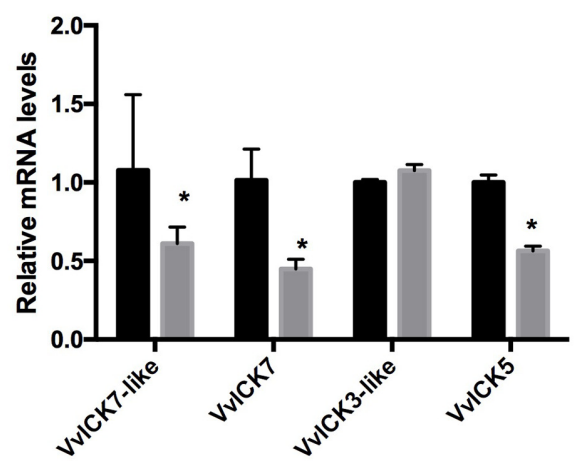

FIGURE 6 | Effect of HC on the expression of (A) cyclin-dependent kinases (VvCDKs), (B) cyclins (VvCYCs), and (C) inhibitors of CDKs (Vv/CKs) in Thompson seedless grapevine buds. Gene expression analysis was performed by RT-qPCR and normalized against VVUBIQUITIN. Values are the average of three biological replicates with three technical repetitions \pm SD; (asterisk) Student's $t$-test $(\alpha=0.05)$.

(del Pozo et al., 2005). In rice, it has been demonstrated that ABA inhibited shoot growth and induced expression of OsKRP4, OsKRP5, and OsKRP6 (Meguro and Sato, 2014).

The transition of bud from a state of dormancy to more active growth has been associated with increased expression of genes that regulate or are involved in the cell cycle (Devitt and Stafstrom, 1995; Shimizu and Mori, 1998; Kebrom et al., 2010). It has been shown that ABA restricts lower bud outgrowth and promotes correlative inhibition in Arabidopsis axillary buds 


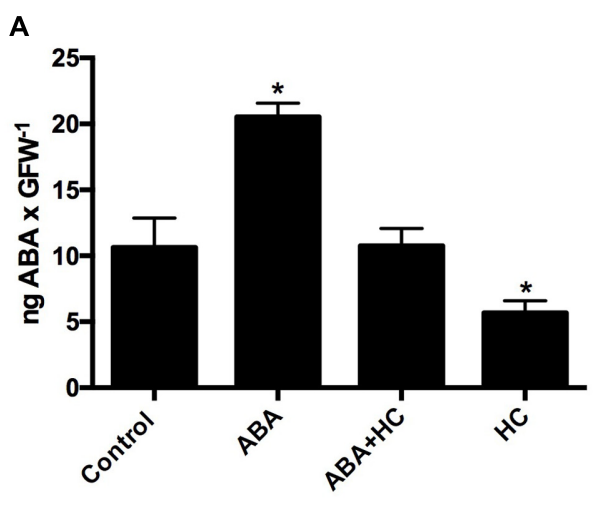

C

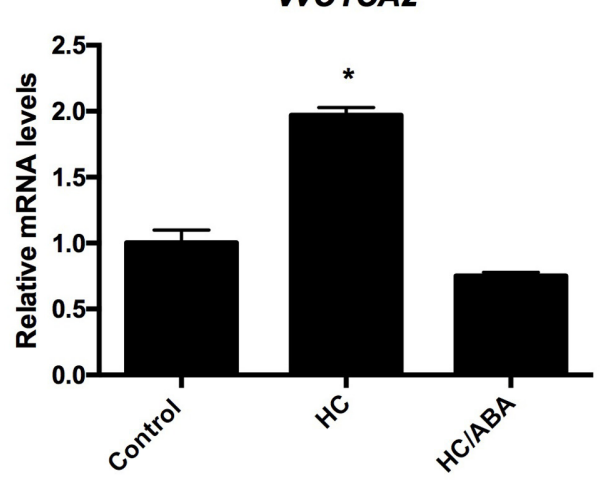

B

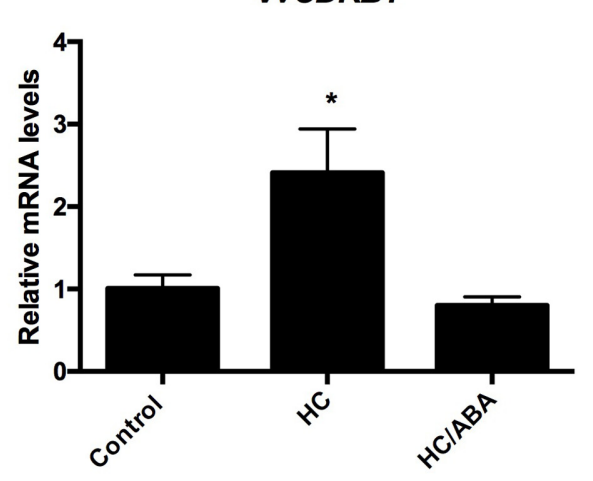

D

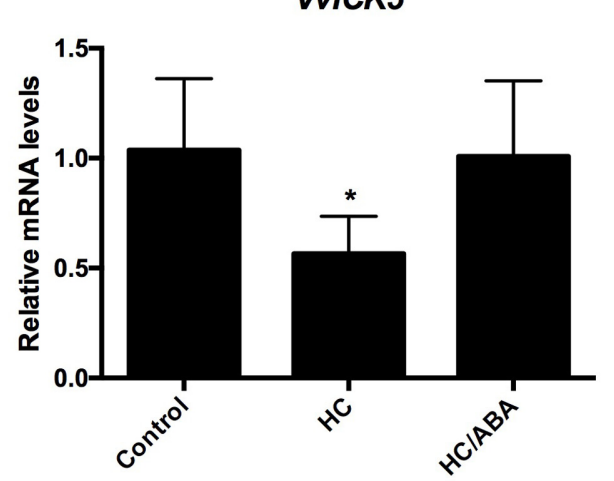

FIGURE 7 | Incorporation of ABA into grapevine buds (A). Co-applications of HC and ABA on the expression of CCG in grapevine buds (B-D). The content of ABA was determined in latent grapevine buds collected on March 23 after the application of the following solutions $100 \mu \mathrm{M} \mathrm{ABA,} 100 \mu \mathrm{M} \mathrm{ABA}+2.5 \% \mathrm{HC}, 2.5 \%$ $\mathrm{HC}$ and water as control. Values are the average of three biological replicates $\pm \mathrm{SD}$; (asterisk) represents significance difference with respect to the control (Dunnett's multiple comparison test $p<0.05$ ). Single-bud cuttings of Thompson seedless grapevine collected on March 23 were sprayed with the following solutions $2.5 \%$ HC, $2.5 \% \mathrm{HC}+100 \mu \mathrm{M}$ ABA and water as control and $48 \mathrm{~h}$ after treatment gene expression analysis was performed by RT-qPCR and normalized against VVUBIQUITIN. Values are the average of three biological replicates with three technical repetitions \pm SD; (asterisk) represents significance difference with respect to the control (Dunnet's multiple comparison test $p<0.05$ ).

(Yao and Finlayson, 2015). Moreover, these authors showed that CCGs CYCLIN A2;1 and PROLIFERATING CELL NUCLEAR ANTIGEN1 (PCNA1) were suppressed by ABA, suggesting that $\mathrm{ABA}$ may inhibit bud growth in part by suppressing elements of the cell cycle machinery.

In this study, the negative relationship found between the content of ABA and the expression level of the CCG at the shoot apex and the latent buds of grapevines, prompted us to investigate the effect of ABA on the expression of CCG in grapevine buds. The fact that ABA down-regulated the expression of genes encoding type B CDKs ( $V v C D K B s)$ and cyclins ( $V v C Y C s)$ and up-regulated the expression of a gene encoding a CDK inhibitor (VvICK5), concurrently with the fact that the concentration of ABA within buds falls within a physiological range after the exogenous application of a $100 \mu \mathrm{M}$ ABA solution, suggests that by modulating the expression of the CCG, ABA could arrests the cell-cycle progression and cell division in meristematic tissues of grapevine. Recently, it has been shown that exogenous application of ABA delays the sprouting of buds and attenuates the effect of $\mathrm{HC}$ on promoting bud break in single-bud cuttings of grapevines (Zheng et al., 2015). Likewise, the fact that $\mathrm{HC}$ besides reducing the content of ABA, up-regulates the expression of CCGs ( $V v C D K B 1, V v C Y C A 3)$ and down-regulates the expression of cell cycle inhibitors ( $V v I C K 5$ and $V v I C K 7)$ suggests that the dormancy breaking effect of $\mathrm{HC}$ could be mediated by ABA. In support of this, co-applications of $\mathrm{HC}$ and $\mathrm{ABA}$ to grapevine buds reduced significantly the expression of CCG relative to HC-treated buds, validating thus the statement that the up-regulation of CCG by HC is mediated by a reduction in $\mathrm{ABA}$ content. Other evidence that support the role of $\mathrm{ABA}$ in the acquisition and maintenance of $\mathrm{ED}$ in grapevine buds is that the SD-photoperiod up-regulates the expression of ABA biosynthetic genes ( $V v N C E D 1, V v N C E D 2)$ (Parada et al., 2016) and simultaneously triggers ED in grapevine buds (Kühn et al., 2009; Grant et al., 2013). Interestingly, when transcript levels of CCG obtained from microarray analysis for bud development of the grape variety Tempranillo grown in the Northern Hemisphere (Díaz-Riquelme et al., 2012) were plotted throughout ED, the expression of genes encoding CDKs $V v C D K A, V v C D K B 1$, and $V v C D K B 2$ and cyclins $V v C Y C A s$ was 
down-regulated, while the expression of the CDK inhibitor VvICK5 was up-regulated. This finding agrees with our results obtained with Thompson seedless grapevine buds grown in the Southern Hemisphere. Moreover, the increases in the content of ABA detected by Zheng et al. (2015) throughout ED in grapevine buds is consistent with results showing a decrease in the expression of CCG, since during ED the bud meristem remains inactive due to the arrest of the cell cycle. Interestingly, $\mathrm{HC}$ up-regulated the expression of $V v C D K B 1$ and $V v C Y C A s$ but down-regulated the expression of $V v C Y C D s$. The D-type cyclins are thought to be sensors of external signals and to play an essential role in the entry of quiescent cells into the cell cycle (Kono et al., 2007), while type A and B cyclins and the CDK $V v C D K B 1$ are expressed during the transition from $\mathrm{S}$ to $\mathrm{M}$ phase and control DNA replication, the G2/M transition, and mitosis. In a previous study, we found that $\mathrm{ABA}$ inhibits respiration in dormant grapevine buds (Parada et al., 2016), and in this work, we found that ABA inhibits cell-cycle progression. Therefore, the question that emerges is if there is a relationship between mitochondrial respiration and cell-cycle progression in grapevine buds. In mammals, it has been reported that the cyclin B1/Cdk1 complex is capable of increasing mitochondrial respiration, with enhanced oxygen consumption and ATP generation during the G2/M transition phase of the cell cycle by phosphorylating a cluster of mitochondrial proteins, including the complex I subunits in the respiratory chain (Wang et al., 2014). Although this interaction has not been reported in plants, it suggests that $\mathrm{ABA}$ may be a master regulator of $\mathrm{ED}$ in grapevine buds since the repression of CCG expression could reduce mitochondrial

\section{REFERENCES}

Arora, R., Rowland, L. J., and Tanino, K. (2003). Induction and release of bud dormancy in woody perennials: a science comes of age. HortScience 38, 911-921.

Campbell, M., Suttle, J., Douches, D. S., and Buell, C. R. (2014). Treatment of potato tubers with the synthetic cytokinin 1-(alpha-ethylbenzyl)-3-nitroguanidine results in rapid termination of endodormancy and induction of transcripts associated with cell proliferation and growth. Funct. Integr. Genomics 14, 789-799. doi: 10.1007/s10142-014-0404-1

Chang, S., Puryear, J., and Cairney, J. (1993). A simple and efficient method for isolating RNA from pine trees. Plant Mol. Biol. Rep. 11,113-116. doi: 10.1007/ BF02670468

de Jager, S. M., Menges, M., Bauer, U. M., and Murray, J. A. H. (2001). Arabidopsis E2F1 binds a sequence present in the promoter of S-phase-regulated gene AtCDC6 and is a member of a multigene family with differential activities. Plant Mol. Biol. 47, 555-568. doi: 10.1023/A:1011848528377

De Veylder, L, Beeckman, T., Beemster, G. T., Krols, L., Terras, F., Landrieu, I., et al. (2001). Functional analysis of cyclin-dependent kinase inhibitors of Arabidopsis. Plant Cell 13, 1653-1667. doi: 10.1105/tpc.13.7.1653

del Pozo, J. C., Lopez-Matas, M. A., Ramírez-Parra, E., and Gutierrez, C. (2005). Hormonal control of the plant cell cycle. Physiol. Plant. 123, 173-183. doi: $10.1111 / \mathrm{j} .1399-3054.2004 .00420 . \mathrm{x}$

Devitt, M. L., and Stafstrom, J. P. (1995). Cell cycle regulation during growthdormancy cycles in pea axillary buds. Plant. Mol. Biol 29, 255-265. doi: 10.1007/ BF00043650

Dhekney, S., Li, Z., Compton, M., and Gray, D. (2009). Optimizing initiation and maintenance of Vitis embryogenic cultures. HortScience 44, 1400-1406.

Díaz-Riquelme, J., Grimplet, J., Martínez-Zapater, J. M., and Carmona, M. (2012). Transcriptome variation along bud development in grapevine (Vitis vinifera $\mathrm{L}$ ). BMC Plant Biology 12:181. doi: 10.1186/1471-2229-12-181 respiration, thus causing the arrest of meristem activity in grapevine buds.

\section{AUTHOR CONTRIBUTIONS}

$\mathrm{RV}$ : planification and revision of the manuscript and performed most of the experiments. XN: performed RT-qPCR experiments. KA: performed ABA determinations. HP: collaborated with experiments carried-out in GSE. FP: planning, design of experiments, and writing of the manuscript.

\section{ACKNOWLEDGMENT}

The financial support of Fondecyt project 1140318 and a doctoral fellowship to RV by Conicyt are gratefully acknowledged.

\section{SUPPLEMENTARY MATERIAL}

The Supplementary Material for this article can be found online at: http://journal.frontiersin.org/article/10.3389/fpls.2017.00812/ full\#supplementary-material

FIGURE S1 | Effect of ABA on the expression of (A) cyclin-dependent kinases $(V v C D K s),(\mathbf{B})$ cyclins ( $V v C Y C s)$, and (C) inhibitors of CDKs ( $V v / C K s)$ on the shoot-apex of Thompson seedless grapevines. Gene expression analysis was performed by RT-qPCR and normalized against VVACTIN. Values are the average of three biological replicates with three technical repetitions.

Gendreau, E., Cayla, T., and Corbineau, F. (2012). S phase of the cell cycle: a key phase for the regulation of thermodormancy in barley grain. J. Exp. Bot. 63, 5535-5543. doi: 10.1093/jxb/ers204

Graeber, K., Nakabayashi, K., Miatton, E., Leubner-Metzger, G., and Soppe, W. J. (2012). Molecular mechanisms of seed dormancy. Plant Cell Environ. 35, 1769-1786. doi: 10.1111/j.1365-3040.2012.02542.x

Grant, T. N. L., Gargrave, J., and Dami, I. E. (2013). Morphological, physiological, and biochemical changes in Vitis genotypes in response to photoperiod regimes. Am. J. Enol. Vitic. 64, 466-475. doi: 10.5344/ajev.2013. 13060

Hemerly, A. S., Ferreira, P., de Almeida Engler, J., Van Montagu, M., Engler, G., and Inzé, D. (1993). cdc2a expression in Arabidopsis is linked with competence for cell division. Plant Cell 5, 1711-1723 doi: 10.1105/tpc.5.12.1711

Hirt, H., Mink, M., Pfosser, M., Bögre, L., Györgyey, J., Jonak, C., et al. (1992). Alfalfa cyclins: differential expression during the cell cycle and in plant organs. Plant Cell 4, 1531-1538 doi: 10.1105/tpc.4.12.1531

Kebrom, T. H., Brutnell, T. P., and Finlayson, S. A. (2010). Suppression of sorghum axillary buds outgrowth by shade, phy B and defoliation signaling pathways. Plant Cell Environ. 33, 48-58. doi: 10.1111/j.1365-3040.2009. 02050.x

Kono, A., Umeda-Hara, C., Adachi, S., Nagata, N., Konomi, M., Nakagawa, T., et al. (2007). The Arabidopsis D-type cyclin CYCD4 controls cell division in the stomatal lineage of the hypocotyl epidermis. Plant Cell 19, 1265-1277. doi: 10.1105/tpc.106.046763

Kühn, N., Ormeño-Nuñez, J., Jaque-Zamora, G., and Pérez, F. J. (2009). Photoperiod modifies the diurnal expression profile of $V v P H Y A$ and $V v P H Y B$ transcripts in field-grown grapevine leaves. J. Plant Physiol. 166, 1172-1180. doi: 10.1016/j.jplph.2009.01.005

Livak, K. J., and Schmittgen, T. D. (2001). Analysis of relative gene expression data using real-time quantitative PCR and the 2- $\Delta \Delta$ CT method. Methods 25, 402-408. doi: 10.1006/meth.2001.1262 
Meguro, A., and Sato, Y. (2014). Salicylic acid antagonizes abscisic acid inhibition of shoot growth and cell cycle progression in rice. Sci. Rep. 4:4555 doi: 10.1038/ srep04555

Morgan, D. (1995). Principles of CDK regulation. Nature 374, 131-134. doi: 10. $1038 / 374131 \mathrm{a} 0$

Newton, R. J. (1977). Abscisic acid effects on fronds and roots of Lemna minor L. Am. J. Bot. 64, 45-49. doi: 10.2307/2441874

Noriega, X., Burgos, B., and Pérez, F. J. (2007). Short-day photoperiod triggers and low temperatures increase expression of peroxidase RNA transcripts and basic peroxidase isoenzyme activity in grapevine-buds. Phytochemitry 68, 1376-1383. doi: $10.1016 /$ j.phytochem.2007.02.003

Olsen, J. (2010). Light and temperature sensing and signaling in induction of bud dormancy in woody plants. Plant Mol. Biol. 73, 37-47. doi: 10.1007/s11103010-9620-9

Parada, F., Noriega, X., Dantas, D., Bressan-Smith, R., and Pérez, F. J. (2016). Differences in respiration between dormant and non-dormant buds suggest the involvement of ABA in the development of endodormancy in grapevines. J. Plant Physiol. 2017, 71-78. doi: 10.1016/j.jplph.2016.07.007

Pines, J. (1995). Cyclins and cyclin- dependent kinases: theme and variations. $A d v$. Cancer Res. 66, 181-212. doi: 10.1016/S0065-230X(08)60254-7

Robertson, J. M., Yeung, E. C., Reid, D. M., and Hubick, K. T. (1990). Developmental responses to drought and abscisic acid in sunflower roots 2 . Mitotic activity. J. Exp. Bot. 41, 339-350

Rohde, A., and Bhalerao, R. P. (2007). Plant dormancy in the perennial context. Trends Plant Sci. 12, 217-223. doi: 10.1016/j.tplants.2007.03.012

Rozen, S., and Skaletsky, H. (2000). Primer3 on the WWW for general users and for biologist programmers. Methods Mol. Biol. 132, 365-386.

Ruttink, T., Arend, M., Morreel, K., Storme, V., Rombauts, S., Fromm, J., et al. (2007). A molecular timetable for apical bud formation and dormancy induction in poplar. Plant Cell 19, 2370-2390. doi: 10.1105/tpc.107.052811

Shimizu, S., and Mori, H. (1998). Analysis of cycles of dormancy and growth in pea axillary buds based on mRNA accumulation pattern of cell cycle related genes. Plant Cell Physiol. 39, 255-262. doi: 10.1093/oxfordjournals.pcp.a029365

Van Overbeek, K., Loeffler, J. E., and Manson, M. I. (1967). Dormin (Abscisin II) inhibitor of plant DNA synthesis? Science 156, 1497-1499.

Vandepoele, K., Raes, J., De Veylder, L., Rouzé, P., Rombauts, S., and Inzé, D. (2002). Genome-wide analysis of core cell cycle genes in Arabidopsis. Plant Cell 14, 903-916. doi: 10.1105/tpc.010445
Verkest, A., Manes, C. L., Vercruysse, S., Maes, S., Van Der Schueren, E., Beeckman, T., et al. (2005). The cyclin- dependent kinase inhibitor KRP2 controls the onset of the endoreduplication cycle during Arabidopsis leaf development through inhibition of mitotic CDKA;1 kinase complexes. Plant Cell 17, 1723-1736. doi: 10.1105/tpc.105.032383

Vermeer, E., Knegt, E., and Bruinsma J. (1987). Determination of abscisic acid in small amounts of plant material. J. Chromatogr. 404, 346-351. doi: 10.1016/ S0021-9673(01)86875-8

Villiers, T. A. (1968). An autoradiographic study of the effect of the plant hormone abscisic acid on nucleic acid and protein metabolism. Planta 82, 342-354. doi: 10.1007/BF00386437

Wang, T. L., Everett, N. P., Gould, A. R., and Street, H. P. (1981). Studies on the control of the cell cycle in cultured plant cells. The effects of cytokinin. Protoplasma 106, 23-35. doi: 10.1007/BF02115959

Wang, Z., Fan, M., Candas, D., Zhang, T. Q., Qin, L., Eldridge, A., et al. (2014). Cyclin B1/Cdk1 coordinates mitochondrial respiration for cellcycle G2/M progression. Dev. Cell 29, 217-232. doi: 10.1016/j.devcel.2014. 03.012

Yao, C., and Finlayson, S. A. (2015). Abscisic acid is a general negative regulator of Arabidopsis axillary bud growth. Plant Physiol. 169, 611-626. doi: 10.1104/pp. 15.00682

Zheng, C. H., Halaly, T., Acheampong, A. K., Takebayashi, Y., Jikumaru, Y., Kamiya, Y., et al. (2015). Abscisic acid (ABA) regulates grape bud dormancy, and dormancy release stimuli may act through modification of ABA metabolism. J. Exp. Bot. 66, 1527-1542. doi: 10.1093/jxb/ eru519

Conflict of Interest Statement: The authors declare that the research was conducted in the absence of any commercial or financial relationships that could be construed as a potential conflict of interest.

Copyright (c) 2017 Vergara, Noriega, Aravena, Prieto and Pérez. This is an openaccess article distributed under the terms of the Creative Commons Attribution License (CC BY). The use, distribution or reproduction in other forums is permitted, provided the original author(s) or licensor are credited and that the original publication in this journal is cited, in accordance with accepted academic practice. No use, distribution or reproduction is permitted which does not comply with these terms. 